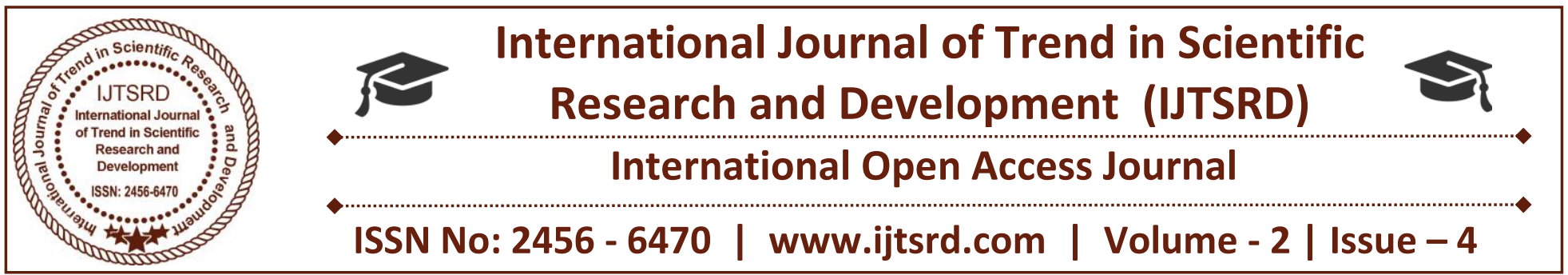

\title{
Assessment of Antioxidants, Phytoactives in Extracts of Colocasia esculenta
}

\author{
Jyothi $\mathbf{R}^{1}$, Srinivasa Murthy $\mathrm{K} \mathrm{M}^{\mathbf{2}}$ \\ ${ }^{1}$ Research Scholar, ${ }^{2}$ Assistant Professor \\ Department of Biotechnology and Microbiology, \\ Bangalore University, Bengaluru, Karnataka, India
}

\section{ABSTRACT}

Colocasia esculenta is a robust perennial plant belonging to Araceae family with a large corm having a very large, heart-shaped leaves that are borne on thick stalks. The young leaves of this plant are rich in Vitamins C, B1, B2, Riboflavin and Niacin. The tubers contain amino acids and are rich in starch. This multipurpose perennial plant is used as a traditional medicine acting as anti-cancer agent, anti-hepatotoxic agent, antimicrobial agent, anti-diabetic agent. This shows the necessity for the study of Colocasia esculenta. In this study, the herbal extracts are distillated using aqueous and ethanol solvents for the antioxidant activity and phytoactives assessment in order to prove the efficiency of Colocasia esculenta role as a potential natural antioxidant. Future studies will reveal the comparison of Colocasia esculenta collected from various regions on their available antioxidant enzymes activity that concludes the biological action of the selected species in therapeutics.

Keywords: Colocasiaesculenta, Extraction, Phytoactives, Natural antioxidant, Antioxidant enzymes

\section{INTRODUCTION}

'Taro' is the common name of genus Colocasia, often described as 'Elephant's ear' is an evergreen, perennial plant that produces a cluster of leaves with a long, erect petioles, growing from $40-200 \mathrm{~cm}$ tall from a large, tuberous rootstock. This species is considered as a very important, staple food crop in many parts of the tropics, with a long history of cultivation. It prefers humid, lowland tropical regions.

\section{SCIENTIFIC CLASSIFICATION:}

Kingdom: Plantae

Order: Alismatales

Family: Araceae

Subfamily: Aroideae

Tribe: Colocasiodeae

Genus: Colocasia

Species: C. esculenta

\section{BOTANICAL STUDY:}

Colocasia esculenta contains 2-3 leaves or more which are green in color. They are ovate, $20-50 \mathrm{~cm}$ long, apex short acuminate, 4 lateral veins; petiole of $20-90 \mathrm{~cm}$ long with solitary inflorescences. Spathe constricted of $20 \mathrm{~cm}$ long with tube green in color, 4 $\mathrm{cm}$ long, $2.2 \mathrm{~cm}$ wide, long-ellipsoid in shape. Spadix is of $10 \mathrm{~cm}$ long, flowers unisexual, female portion is 3-3.5 cm long, $1.2 \mathrm{~cm}$ wide, conic, slender; male portion $4-4.5 \mathrm{~cm}$ long, $7 \mathrm{~mm}$ wide, cylindrical. It is often established in low lying areas along streams and river banks.

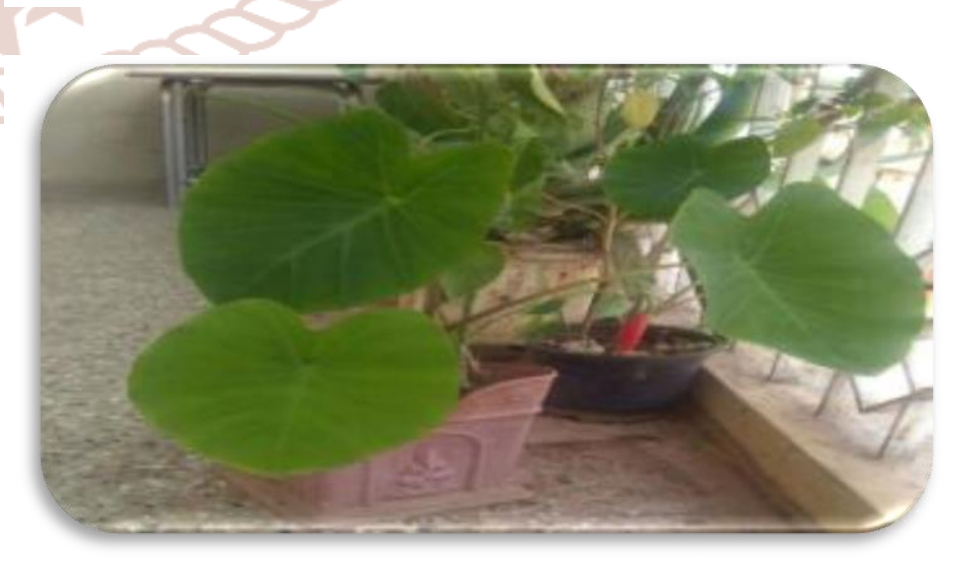

Figure 1: Colacassiaesculenta 


\section{Medicinal values}

$>$ The plant possess antibacterial properties

$>$ The extract of leaves is drunk to promote menstruation

$>$ The extract is taken to relieve stomach problems and to treat cysts

$>$ The sap of the leaf stalk is used in treating conjunctivitis

$>$ The plant is used to treat wounds.

$>$ The leaves are rich in nutrients such as Calcium, Phosphorous and Iron; minerals and vitamins like C, Riboflavin, Thiamine, Niacin.

$>$ Fresh edible leaves of the selected plant are rich source of protein, ascorbic acid, fibres.

With all the above medicinal properties, the plant also contains calcium oxalate crystals which are responsible for causing an extremely unpleasant sensation similar to needles being stuck into the mouth and tongue if they are eaten, hence, the leaves can be neutralized by drying or cooking thoroughly or by steeping it in water.

\section{PHYTOACTIVES:}

Pharmocological importance of plants has been gaining attention due to zero toxicity and less expense. Potential components from various parts of th plants have been identified and their extract is used for the formulation of drugs. Modern clinical drugs includes the use of natural extract's origin which possess the presence of phytoactives such as Alkaloids, Glycosides, Proteins, Carbohydrates, Lipids, Fats and Oils because of which they are known for the lower incidence of the adverse effects caused by the drugs.

\section{MATERIALS AND METHODS}

\section{Specimen collection:}

The plant samples were collected from Shettyhalli village, SakleshpuraTaluk, Hassan district, Karnatakaand authenticated in Regional Ayurveda Institute for Metabolic Disorders, Govt. of India in order to confirm the plant species. The leaves as the sample were excised from the collected plant.

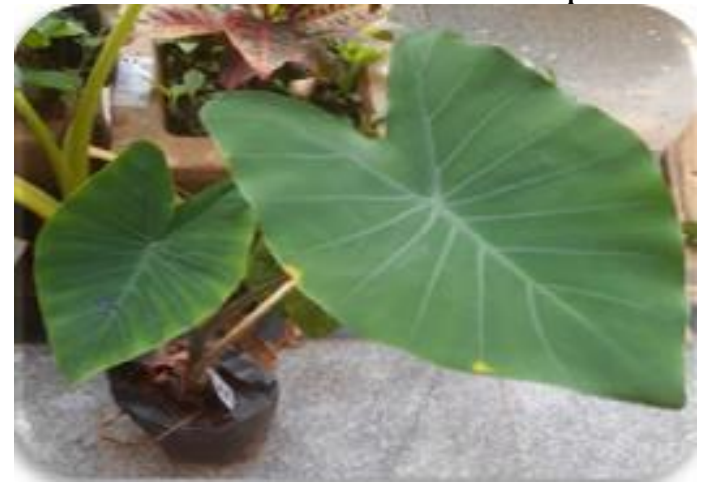

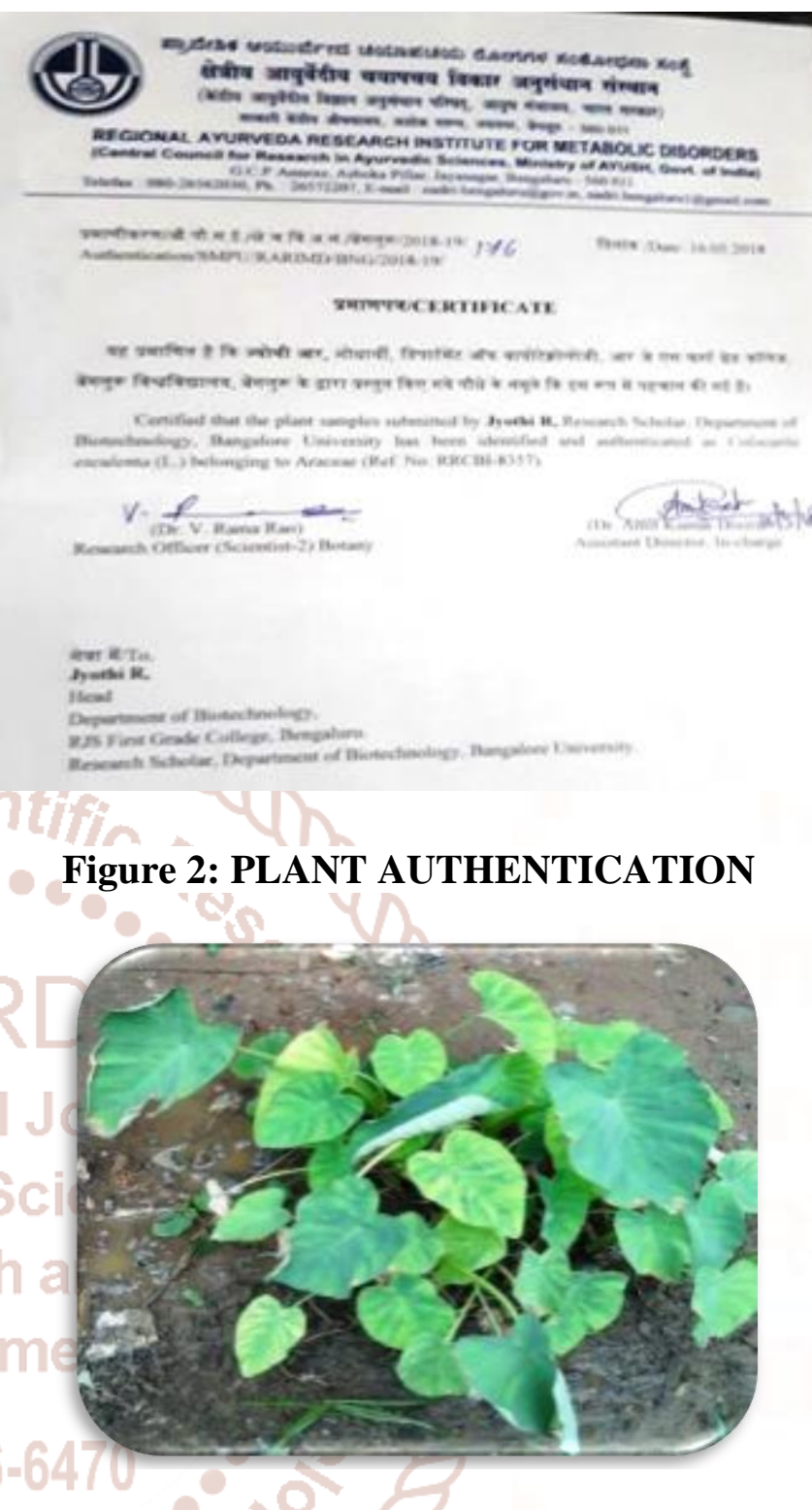

Figure 3: COLLECTEDPLANT SPECIES

\section{PLANT EXTRACTION:}

The leaves were subjected to extraction using water and ethanol as solvents at room temperature using Soxhlet apparatus where in the collected extracts were stored at $4{ }^{\circ} \mathrm{C}$ until use.

QUALITATIVE

PHYTOACTIVE:

ANALYSIS

OF

\section{Test for Alkaloids}

Dragendorff's test: To the $1 \mathrm{ml}$ of extract, $1 \mathrm{ml}$ of Dragendorff's reagent (potassium bismuth iodide solution) was added. An orange-red precipitate indicated the presence of alkaloids.

Wagner's test: To the $1 \mathrm{ml}$ of extract $2 \mathrm{ml}$ of Wagner's reagent (iodine in potassium iodide)was 
added .The formation of reddish brown precipitate indicated the presence of alkaloids.

Test for Saponins: Small quantity of alcoholic and aqueous extracts were taken separately and to this $20 \mathrm{ml}$ of distilled water was added and was shook well vertically in a graduated cylinder for 15 minutes . Layer of foam indicated the presence of Saponins.

\section{$>$ Test for Glycosides:}

Legal's test: The extract was dissolved in pyridine and to this sodium nitropruside solution was added to make it alkaline. The change from pink to red colour shows the presence of glycosides.

Baljet's test: To $1 \mathrm{ml}$ of the test extract, $1 \mathrm{ml}$ of sodium picrate solution was added and the yellow to orange color reveals the presence of glycosides.

\section{Test for Carbohydrates}

Molisch'stest:To $2 \mathrm{ml}$ of the extract, $1 \mathrm{ml}$ of anapthol solution was added, followed by concentrated sulphuric acid through the side of the test tube. Purple or reddish violet color at the junction of the two liquids reveals the presence.

Fehling's test: To $1 \mathrm{ml}$ of the extract, equal quantities of Fehling solution $\mathrm{A}$ and $\mathrm{B}$, were added, upon heating formation of a brick red precipitate indicates the presence of sugars.

Benedict's test: To $5 \mathrm{ml}$ of Benedict's reagent, $1 \mathrm{ml}$ of extract solution was added, boiled for 2 minutes and cooled. Formation of red precipitate shows the presence of sugars.

\section{Test for Tannins}

the little quantity of test solution was taken and mixed with basic lead acetate solution. Formation of white precipitate indicates the presence of tannins. ii) To $1 \mathrm{ml}$ of the extract, ferric chloride solution was added; formation of a dark blue or greenish black color product shows the presence of tannins. The little quantity of the extract was treated with potassium ferric cyanide and ammonia solution. A deep red color indicates the presence of tannins. iii) To the test extract, strong potassium dichromate solution was added, a yellow color precipitate indicates the presence of tannins and Phenolic compounds.

\section{Test for Flavonoids}

Shinoda's Test: i) The extract was treated with sodium hydroxide; formation of yellow color indicates the presence of flavones. ii) The extract was treated with concentrated $\mathrm{H} 2 \mathrm{SO} 4$, formation of yellow or orange color indicates flavones.

\section{$>$ Test for Steroids}

\section{Salkowski test:}

The extract was dissolve in chloroform and equal volume of conc. H2SO4 was added. Formation of bluish red to cherry color in chloroform layer and green fluorescence in the acid layer represents the steroidal components in the tested extract.

\section{Test for Fats \& Oils}

A thick section of extract was placed on glass slide. a drop of Sudan Red III reagent was added. After 2 min. wash with $50 \%$ alcohol and was mounted in glycerin, Observed under microscope. Oil globules appear red. ii) Little amount of extract was placed on the filter paper and allowed to stand for 15 minutes. A greasy spot observe due to presence of fats.

\section{QUANTITATIVE}

ANTIOXIDANTS:

\section{ANALYSIS}

FOR

\section{DETERMINATION OF CARBOHYDRATE}

$100 \mathrm{mg}$ of sample was hydrolyzed in a boiling tube with $5 \mathrm{ml}$ of $2.5 \mathrm{~N} \mathrm{HCl}$ in a boiling water bath for a period of 3 hours. It was cooled to room temperature and solid sodium carbonate was added until effervescence ceases. The contents were centrifuged and the supernatant was made to $100 \mathrm{ml}$ using distilled water. From this $0.2 \mathrm{ml}$ of sample was pipette out and made up the volume to $1 \mathrm{ml}$ with distilled water. Then $1.0 \mathrm{ml}$ of phenol reagent was added followed by $5.0 \mathrm{ml}$ of sulphuric acid. The tubes were kept at $25-30^{\circ} \mathrm{C}$ for $20 \mathrm{~min}$. The absorbance was read at $490 \mathrm{~nm}$.

\section{DETERMINATION OF PROTEIN}

The dried and powdered samples were extracted by stirring with $50 \mathrm{ml}$ of $50 \%$ methanol $(1: 5 \mathrm{w} / \mathrm{v})$ at 25 ${ }^{\circ} \mathrm{C}$ for $24 \mathrm{hrs}$. and centrifuged at 7,000 rpm for $10 \mathrm{~min}$ $.0 .2 \mathrm{ml}$ of extract was pipette out and the volume was made to $1.0 \mathrm{ml}$ with distilled water. $5.0 \mathrm{ml}$ of alkaline copper reagent was added to all the tubes and allowed 
it to stand for $10 \mathrm{~min}$. Then $0.5 \mathrm{ml}$ of Folin-Ciocalteau reagent was added and incubated in dark for $30 \mathrm{~min}$. The intensity of the colour developed was read at 660 $\mathrm{nm}$.

\section{DETERMINATION OF TOTAL PHENOLICS}

Ten micro litre aliquots of the extracts $(2 \mathrm{mg} / 2 \mathrm{ml})$ was taken in test tubes and made up to the volume of $1 \mathrm{ml}$ with distilled water. Then $0.5 \mathrm{ml}$ of FolinCiocalteu phenol reagent (1:1 with water) and $2.5 \mathrm{ml}$ of sodium carbonate solution (20\%) were added sequentially in each tube. Soon after vortexing the reaction mixture, the test tubes were placed in dark for $40 \mathrm{~min}$ and the absorbance was recorded at $725 \mathrm{~nm}$ against the reagent blank. The analysis was performed in triplicate and the results were expressed as tannic acid equivalents.

\section{DETERMINATION OF TOTAL FLAVONOID CONTENT}

The flavonoid content was determined by the use of a slightly modified colorimetric method described. A $0.5 \mathrm{ml}$ aliquot of appropriately $(2 \mathrm{mg} / 2 \mathrm{ml})$ diluted sample solution was mixed with $2 \mathrm{ml}$ of distilled water and subsequently with $0.15 \mathrm{ml}$ of $5 \% \mathrm{NaNO} 2$ solution. After $6 \mathrm{~min}, 0.15 \mathrm{ml}$ of $10 \%$ aluminium chloride solution was added and allowed to stand for $6 \mathrm{~min}$, and then $2 \mathrm{ml}$ of $4 \%$ sodium hydroxide solution was added to the mixture. Immediately, water was added to bring the final volume to $5 \mathrm{ml}$, and then the mixture was thoroughly mixed and allowed to stand for another $15 \mathrm{~min}$. Absorbance of the mixture was determined at $510 \mathrm{~nm}$ versus water blank. The analysis was performed in triplicate and the results were expressed as rutin equivalent.

\section{DPPH FREE RADICAL SCAVENGING ASSAY:}

The radical scavenging activity of selected root extracts was determined. $4.3 \mathrm{mg}$ of DPPH $(2,2-$ Diphenyl -1- picrylhydrazyl) was dissolved in methanol $(6.6 \mathrm{ml})$ to prepare $0.3 \mathrm{mM}$ DPPH solution and it was protected from light by covering the test tubes with aluminium foil. DPPH $(150 \mu \mathrm{l})$ was added to $3 \mathrm{ml}$ of methanol and absorbance was noticed immediately at $516 \mathrm{~nm}$ for control reading. Different concentrations of test samples i.e $25 \mu \mathrm{l}, 50 \mu \mathrm{l}, 100 \mu \mathrm{l}$, $150 \mu \mathrm{l}, 200 \mu \mathrm{l}$ and $250 \mu \mathrm{l}$ were taken and each of the samples was diluted with methanol up to $3 \mathrm{ml}$, to it $150 \mu \mathrm{l}$ DPPH was added. The samples were kept in dark for $15 \mathrm{~min}$ after which the optical density was observed at $516 \mathrm{~nm}$ using methanol as blank.
$\mathrm{S} \%$ Antioxidant activity $=$ (Control Absorbance Sample Absorbance) $\times 100$

Control Absorbance

\section{DETERMINATION OF TOTAL REDUCING POWER}

$1 \mathrm{ml}$ of the extract $(1 \mathrm{mg} / \mathrm{ml})$ was mixed with $1 \mathrm{ml}$ of $200 \mathrm{mM}$ of sodium phosphate buffer (pH- 6.6) and $1 \mathrm{ml}$ of $1 \%$ potassium ferricyanide. The mixture was incubated at $50^{\circ} \mathrm{C}$ for $20 \mathrm{~min}$ and $1 \mathrm{ml}$ of $10 \%$ trichloroacetic acid (w/v) was added. The mixture was centrifuged at 2000rpm for $10 \mathrm{~min}$. The upper layer solution $(2.5 \mathrm{ml})$ was mixed with $2.5 \mathrm{ml}$ of double deionised water and $1 \mathrm{ml}$ of fresh ferric chloride solution $(0.1 \%)$. The absorbance was measured at 700nm. A higher absorbance indicated a higher reducing power.

\section{RESULTS AND DISCUSSION}

The leaves of the plant from araceae family were subjected to qualitative and quantitative analysis and the results were tabulated.

\section{PHYTOCHEMICAL ANALYSIS}

Phytochemicals are bioactive non-nutrient plant compounds that provide a wide range of activities in treating the diseases/disorders. They protect the plants from harmful agents such as insects and microbes as well as stressful/extreme temperatures. The phytochemical constituents present in the plant sample were estimated with the extraction of Ethanol and Water as solvents.

\begin{tabular}{|l|c|c|}
\hline \multicolumn{1}{|c|}{ EXTRACT } & Water & Ethanol \\
\hline ALKALOIDS & & \\
(WAGNER'S TEST) & + & + \\
\hline $\begin{array}{l}\text { CARBOHYDRATES } \\
\text { MOLISCH'S TEST }\end{array}$ & + & + \\
\cline { 2 - 3 } $\begin{array}{l}\text { FEHLINGS TEST } \\
\text { BENEDICTS TEST }\end{array}$ & + & + \\
\hline TANNINS & - & - \\
\hline $\begin{array}{l}\text { FLAVONOIDS } \\
\text { SHINODA TEST }\end{array}$ & + & + \\
\hline SAPONINS & - & - \\
\hline $\begin{array}{l}\text { FIXED OILS } \\
\text { SPOT TEST }\end{array}$ & - & - \\
\hline $\begin{array}{l}\text { GLYCOSIDES } \\
\text { BORNTRAGERS } \\
\text { TEST }\end{array}$ & + & + \\
\hline
\end{tabular}


On the whole, the Colocasia esculenta extracts showed positive results in the analysis of phytochemicals where the saponins and oils were absent in the extract and tannins were absent; all the other phytochemicals showed their presence in both the extracts which proved the ability of the plant extracts to perform wide range of defense mechanisms.
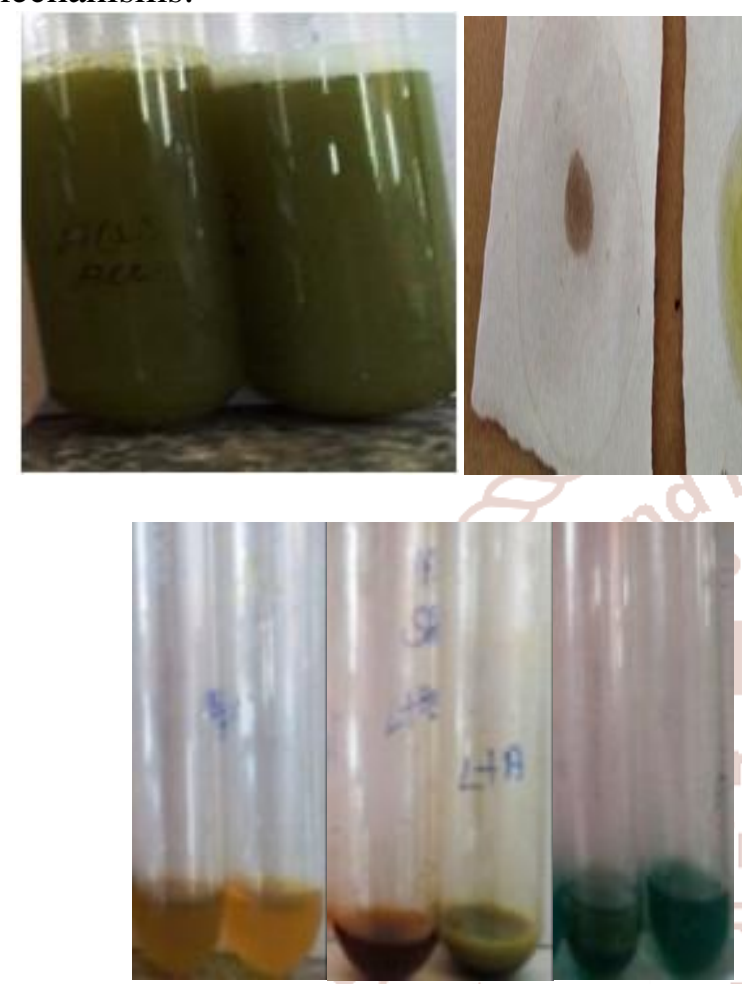

Figure 4: PHYTOACTIVES

\section{QUANTITATIVE ANALYSIS:}

\section{TOTAL FLAVONOIDS:}

Some flavonoids have inhibitory activity against organisms that cause plant diseases. Flavonoids are the most important plant pigments for flower coloration, producing yellow or red/blue pigmentation in petals designed to attract pollinator animals. Flavonoids are generally secreted by the root of the host plant.

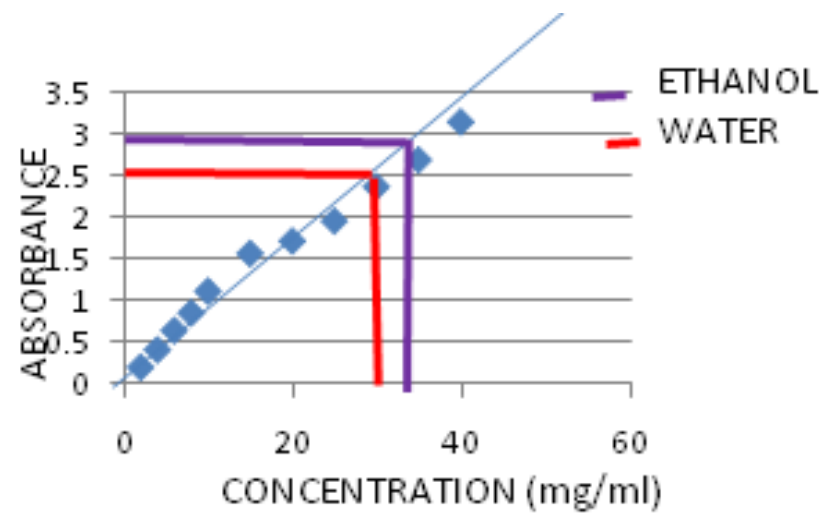

Graph 1: Graph showing the Total Flavonoids
From the graph, the total flavonoids were estimated in both the extracts and found to be $30.6 \mathrm{mg} / \mathrm{ml}$ in ethanol and $28.7 \mathrm{mg} / \mathrm{ml}$ in water extract.

\section{REDUCING POWER ASSAY:}

It is a measure of antioxidant activity to reduce other substances, or the environment. and reduce to other substances means addition of hydrogen and removal of oxygen and also gain of electron.

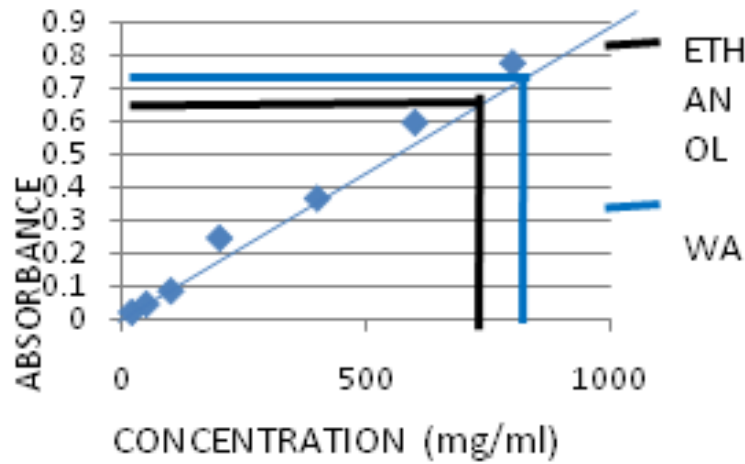

Graph 2: Graph showing Reducing power

From the graph, the reducing power was estimated in both the extracts and found to be $700 \mathrm{mg} / \mathrm{ml}$ in ethanol and $802 \mathrm{mg} / \mathrm{ml}$ in water extract.

\section{DETERMINATION OF TOTAL PHENOLIC CONTENT:}

Phenolic compounds are plant substances which possess in common an aromatic ring bearing one or more hydroxyl groups. There are about 8000 naturally occurring plant phenolics and about half of these numbers are flavonoids. Phenolics possess a wide spectrum of biochemical activities such as antioxidant, antimutagenic, anticarcinogenic as well as ability to modify the gene expression. Phenolics are the largest group of phytochemicals that account for most of the antioxidant activity in plants or plant products.

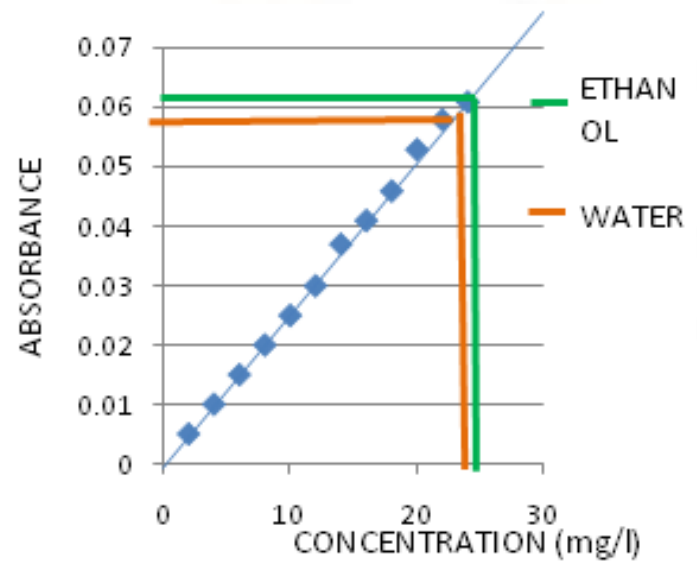

Graph 3: Graph showing the Total Phenolics 
From the graph, total phenolics was estimated in both the extracts and found to be almost the same of about $26 \mathrm{mg} / \mathrm{ml}$ in ethanol and $25 \mathrm{mg} / \mathrm{ml}$ in water extract.

\section{DPPH RADICAL SCAVENGING:}

DPPH is a free radical with red color which turns into yellow color after scavenging at the specific absorbance. The degree of discoloration indicates the scavenging potential of the antioxidant compounds in terms of hydrogen donating ability.

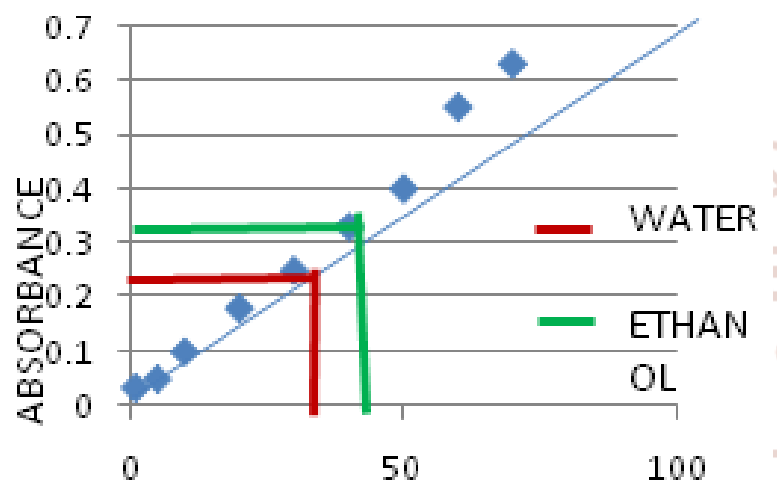

CONCENTRATION $(\mathrm{mg} / \mathrm{ml})$

\section{Graph 4: Graph showing the DPPH activity}

From the graph, DPPH was estimated in both the extracts and found to be almost the same of about 46 $\mathrm{mg} / \mathrm{ml}$ in ethanol and $40.6 \mathrm{mg} / \mathrm{ml}$ in water extract.

\section{PROTEIN ESTIMATION:}

Proteins are the most complex and abundant of the macro molecules. Within cells, many proteins function as enzymes in the catalysis of metabolic reactions

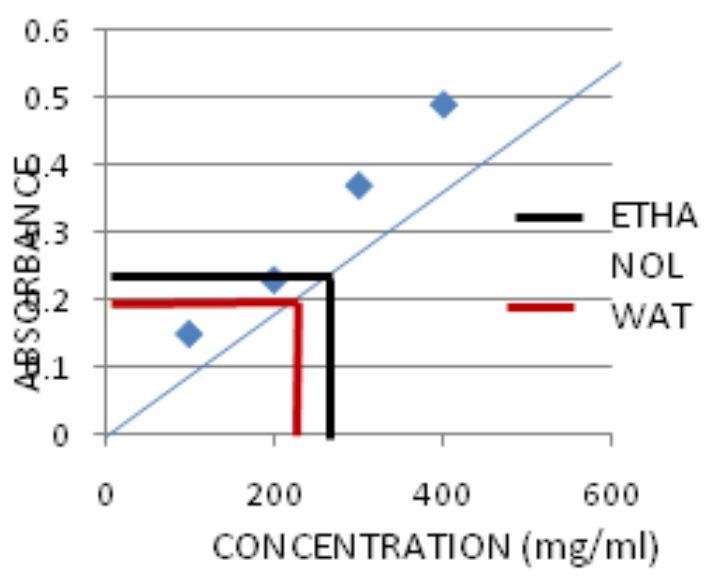

Graph 5: Graph showing the Total Proteins
From the graph, total proteins were estimated in both the extracts as $199 \mathrm{mg} / \mathrm{ml}$ in ethanol and $182 \mathrm{mg} / \mathrm{ml}$ in water extract.

\section{CARBOHYDRATE ESTIMATION:}

Carbohydrates are an essential compound of all organic life on this planet. Both plants and animals use carbohydrates as a primary source of energy, which keeps the body functioning at the most basic level. Carbohydrates also fulfill other needs by helping in the synthesizing of other chemicals and providing structure for cells within the body. Carbohydrates also serve as antigens, substances which trigger the creation of antibodies for the immune system. Other carbohydrates provide hormones, such as follicular stimulating hormone (FSH), which aids in ovulation, and glycoprotein, which aids in cell-to-cell interaction such as those between antigens and antibodies.

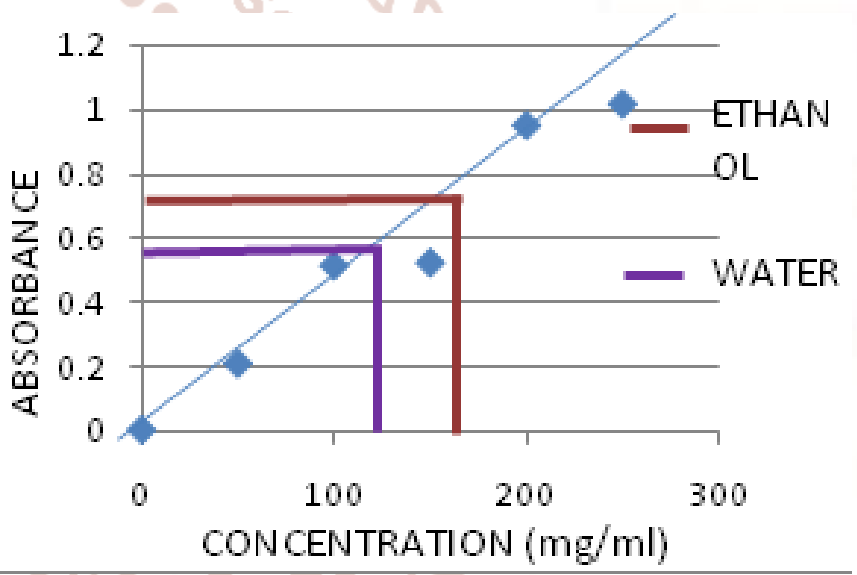

Graph 6: Graph showing the Total Carbohydrates

From the graph, total proteins were estimated in both the extracts as $155.7 \mathrm{mg} / \mathrm{ml}$ in ethanol and 134.6 $\mathrm{mg} / \mathrm{ml}$ in water extract.

\section{CONCLUSION:}

In the selected plant, the antioxidant and phytochemicals were found to be maximum, which paves way for the antioxidant enzymes activity in order to prove the therapeutic importance. This leaves extract was found to possess inhibitory effect against three microbes. Further investigations on this leaves extract can reveal various biological mechanisms present in them.

\section{ACKNOWLEDGEMENT}

The authors record their sincere thanks to Chairman and Faculties of Department of Biotechnology and Microbiology. Many thanks to Shri. Gopala Krishna 
Bhat, Retd. Prof. Udupi, Mrs. PrasannaBhat, Udupi, Dr. Rama Rao, Regional Ayurveda Research Institute for Metabolic Disorders, Bengaluru for their timely support. A special thanks to Dr. V. Palani, Managing Director, Founder and Managing Director of Genewin Biotech, Hosur and Ms. Parvathy. S, R and D Manager for their support throughout the work.

\section{REFERENCES:}

1. T. V. Krishnapriya, A. Suganthi, "Biochemical and Phytochemical analysis of Colocassiaesculenta (L.) Schott tubers"., Int. J. Res. Pharm. Pharm. Sci., 2 (3), 2017, 21-25.

2. Patrícia R. Pereira, Joab T. Silva, Vânia M. F. Paschoalin Gerlinde A. P. B. Teixeira, "Crude extract from taro (Colocasiaesculenta) as a natural source of bioactive proteins able to stimulate haematopoietic cells in two murine models", J. Func. Foods, 18, 2015, 333-343
3. Prasan R. Bhandari, Mohammad AmeeruddinKamdod, "Emblicaofficinalis(Amla): A review of potential therapeutic applications", Ind. J. Green Pharm., 2012, 257-269

4. Bhattacharya A, Chatterjee A, Ghosal S, Bhattacharya SK, "Antioxidant activity of active tannoid principles of Emblicaofficinalis (amla)", Ind. J. Exp. Biol., 37 (7), 1999, 676 - 680.

5. Sreeja Sreekumar, Hima Sithul, Parvathy Muraleedharan, Juberiya Mohammed Azeez, and Sreeja Sreeharshan, "Pomegranate Fruit as a Rich Source of Biologically Active Compounds", BioMed Research International, 2014

6. Fabricant DS, Fansworth NR, "The value of plants used in traditional medicine for drug discovery". Environment Health Perspective. 109, 2001, 69-75

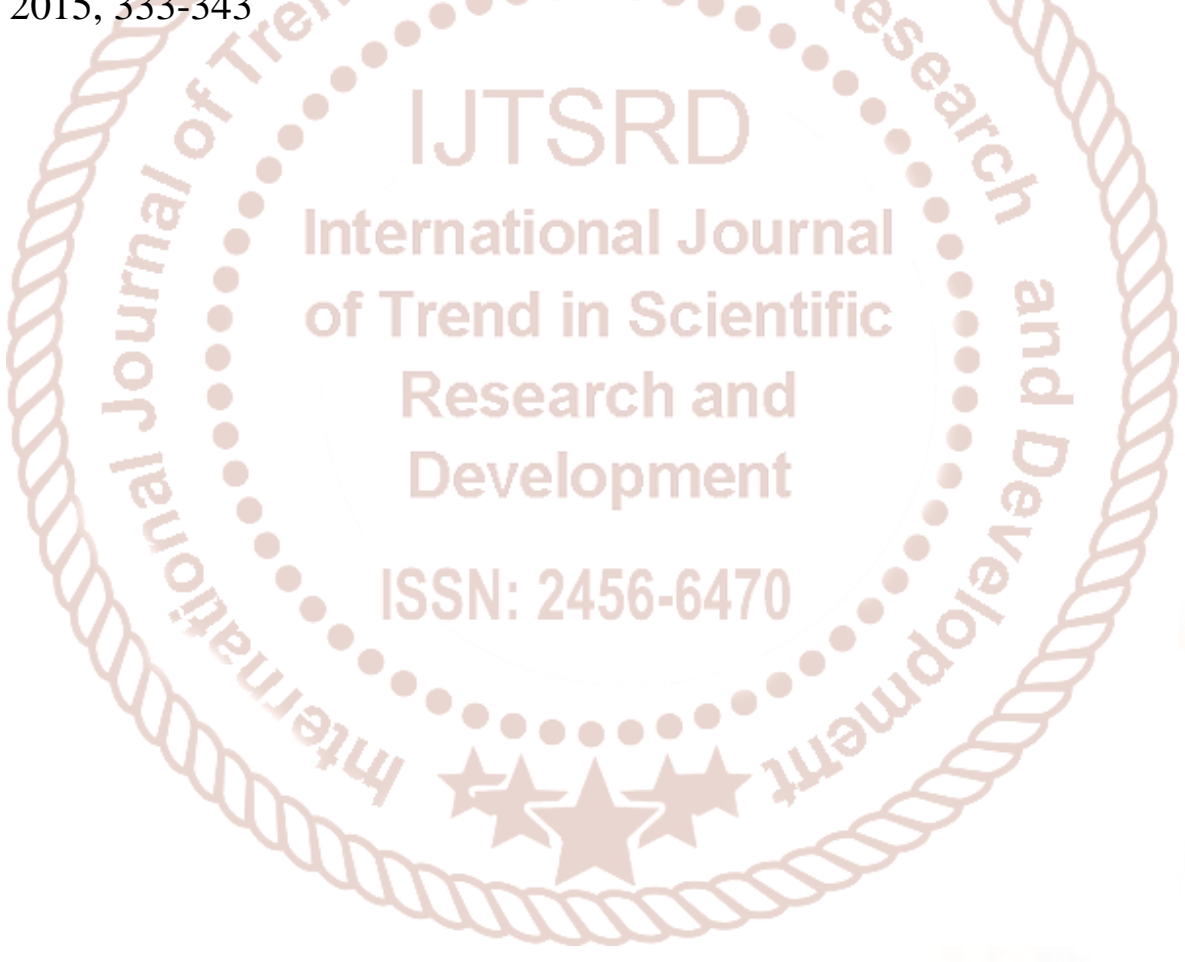

